\title{
PENGARUH IKLIM ORGANISASI, KEPEMIMPINAN, KEMAMPUAN KERJA, DAN DISIPLIN KERJA TERHADAP KINERJA APARATUR SIPIL NEGARA (ASN) KABUPATEN INDRAGIRI HULU
}

\author{
Khusnul Fikri \\ Program Studi Manajemen, Sekolah Tinggi Ilmu Ekonomi Indragiri (STIE-I) Rengat \\ Email: khusnul fikri@stieindragiri..ac.id
}

\begin{abstract}
Abstrak
Penelitian ini dilaksanakan di Kabupaten Indragiri Hulu. Perumusan masalah adalah apakah iklim organisasi, kepemimpinan, kemampuan kerja, dan disiplin kerja secara simultan dan secara parsial berpengaruh signifikan terhadap kinerja Aparatur Sipil Negara (ASN) Kabupaten Indragiri Hulu. Tujuan penelitian adalah untuk mengetahui dan menganalisis pengaruh iklim organisasi, kepemimpinan, kemampuan kerja, dan disiplin kerja secara simultan dan secara parsial terhadap kinerja Aparatur Sipil Negara (ASN) Kabupaten Indragiri Hulu.

Dalam penelitian ini, penulis menggunakan pengambilan sampel dengan Rumus Slovin, yakni diperoleh sampel sebanyak 97 responden. Responden dalam penelitian ini adalah Aparatur Sipil Negera Kabupaten Indragiri Hulu yang berstatus Pegawai Negeri Sipil. Analisa data yang digunakan dalam penelitian ini yaitu analisa deskriptif dan analisa kuantitatif.

Hasil penlitian dapat disimpulkan bahwa scara simultan iklim organisasi, kepemimpinan, kemampuan kerja dan disiplin kerja secara bersama-sama berpengaruh signifikan terhadap kinerja Aparatur Sipil Negara. Iklim organisasi secara parsial berpengaruh signifikan terhadap kinerja, artinya semakin baik iklim organisasi maka akan meningkatkan kinerja Aparatur Sipil Negara. Kepemimpinan secara parsial berpengaruh signifikan terhadap kinerja, artinya semakin meningkat kepemimpinan maka kinerja Aparatur Sipil Negara juga akan meningkat. Kemampuan kerja secara parsial berpengaruh signifikan terhadap kinerja, artinya semakin meningkat kemampuan kerja, maka akan meningkatkan kinerja Aparatur Sipil Negara. Disiplin kerja secara parsial berpengaruh signifikan terhadap kinerja, artinya semakin bagus disiplin kerja, maka akan meningkat pula kinerja Aparatur Sipil Negara, variabel yang paling dominan yang mempengaruhi kinerja Aparatur Sipil Negara adalah variabel iklim organisasi.
\end{abstract}

Kata Kunci: Iklim Organisasi, Kepemimpinan, Kemampuan Kerja, Disiplin Kerja, Kinerja

\section{PENDAHULUAN}

Dalam konteks administrasi negara, peran sumber daya aparatur menjadi unsur yang sangat vital bagi berlangsungnya kehidupan pemerintahan dan pembangunan. Di Indonesia peran tersebut dimainkan oleh pegawai negeri sipil, yang dalam pemerintahan seringkali disebut sebagai "mesin birokrasi". Sorotan utama terhadap terciptanya good governance dan mengenai perlunya diciptakan clean government serta efisien menjadikan peran pegawai negeri sipil menjadi perhatian yang cukup serius. Artinya, pembenahan pegawai negeri sipil harus menjadi pusat perhatian karena memiliki fungsi yang sangat strategis. Kebutuhan akan reformasi menuju terciptanya pegawai negeri sipil yang efisien semakin dirasakan sejalan dengan perubahan-perubahan yang terjadi sebagai hasil dari 
pembangunan dan akibat perubahan eksternal pada tingkat regional dan global. Kecenderungan umum dalam pertumbuhan di segala bidang juga melahirkan tuntutan mengenai perlunya pegawai negeri sipil yang lebih profesional, terampil, terbuka dan berorientasi pelayanan kepada masyarakat (Utama, 2010:1).

Dibentuknya Undang-Undang Republik Indonesia Nomor 32 Tahun 2004 tentang Pemerintahan Daerah sebagai pengganti Undang-Undang Republik Indonesia Nomor 22 Tahun 1999, diharapkan dapat menjawab kebutuhan dasar masyarakat menyangkut peningkatan pelayanan dan kesejahteraan masyarakat, pelaksanaan demokratis, akuntabilitas, efisiensi dan efektivitas, transparansi dalam penyelenggaraan pemerintah, penghormatan terhadap hak asasi manusia, pemberdayaan masyarakat, penumbuhan prakarsa dan kreativitas, serta meningkatnya peran serta masyarakat di daerah.

Sejalan dengan hal tersebut, dalam rangka menunjang pelaksanaan pemerintahan dan pembangunan di daerah, tentunya diperlukan aparatur negara (PNS) yang lebih profesional, bermoral, bersih serta bertanggung jawab. Pegawai negeri sipil yang diatur di dalam Undang-Undang Republik Indonesia Nomor 5 Tahun 2014 tentang Aparatur Sipil Negara berfungsi sebagai pelaksanaan kebijakan publik, pelayan publik, dan perekat dan pemersatu bangsa. Pegawai negeri sipil bertugas melaksanakan kebijakan publik yang dibuat oleh pejabat pembina kepegawaian sesuai dengan ketentuan Peraturan PerundangUndangan, memberikan pelayanan publik yang profesional dan berkualitas, dan mempererat persatuan dan kesatuan Negara Kesatuan Republik Indonesia. Untuk itu, dalam rangka pelaksanaan cita-cita bangsa serta mewujudkan tujuan negara sebagaimana tercantum dalam pembukaan Undang-undang Dasar Negara Republik Indonesia Tahun 1945, perlu dibangun aparatur sipil negara yang memiliki integritas, profesional, netral dan bebas dari intervensi politik, bersih dari praktik korupsi, kolusi dan nepotisme serta mampu menyelenggarakan pelayanan publik bagi masyarakat dan mampu menjalankan peran sebagai unsur perekat persatuan dan kesatuan bangsa berdasarkan Pancasila dan Undang-undang Dasar Negara Republik Indonesia Tahun 1945.

Sasmita (2012:80), disebutkan bahwa Pegawai Negeri Sipil (PNS) merupakan aparatur negara yang menyelenggarakan pemerintahan dalam melaksanakan pembangunan nasional merupakan tulang punggung pemerintah. Kelancaran penyelenggaraan pemerintahan dan pelaksanaan pembangunan nasional terutama tergantung pada kesempurnaan aparatur negara baik ditingkat pusat maupun ditingkat daerah. Syabrus (2009:168), sebagai abdi masyarakat dan negara, pegawai harus senantiasa meningkatkan kemampuan, keterampilan, pendidikan, pengalaman, dan profesionalisme-nya agar mereka dapat menjalankan tugas dan kewajibannya dalam rangka meningkatkan pelayanan kepada masyarakat.

Banyak permasalahan yang berkaitan dengan birokrasi di Indonesia, Abubakar (2014:4), menyatakan bahwa permasalahan birokrasi di Indonesia yang ditunjukkan dengan masih tingginya korupsi, masih rendahnya pelayanan publik, serta masih rendahnya kapasitas dan akuntabilitas kinerja organisasi. Sedarmayanti (2007:10) menyebutkan bahwa birokrasi di Indonesia dicitrakan sebagai sesuatu yang bertele-tele, sering rapat, sering seminar, banyak bicara, saling menyalahkan, suka membuat berbagai panitia, jam karet, tidak efisien dan korup. Selanjutnya, disebutkan bahwa perlunya dilaksanakan pembenahan oleh pemerintah terhadap kinerja PNS dalam rangka mengantisipasi tantangan globalisasi.

Menurut laporan Global Competetitiveness Report dari World Economic Forum, menyebutkan rangking kemampuan daya saing Indonesia pada tahun 2015-2016 berada pada peringkat 37 (skor 4.52) dari 140 Negara yang dinilai, turun 3 peringkat pada tahun 2014-2015 berada pada peringkat 34 (skor 4.57). Penilaian peringkat daya saing global ini didasarkan pada 113 indikator yang dikelompokkan dalam 12 pilar daya saing. Kedua 
belas pilar tersebut yaitu institusi, infrastruktur, kondisi dan situasi ekonomi makro, kesehatan dan pendidikan dasar, pendidikan tingkat atas dan pelatihan, efisiensi pasar, efisiensi tenaga kerja, pengembangan pasar finansial, kesiapan teknologi, ukuran pasar, lingkungan bisnis, dan inovasi. Di level ASEAN, peringkat Indonesia masih berada dibawah tiga negara tetangga, yaitu Singapura yang berada di peringkat 2, Malaysia di peringkat 18 dan Thailand yang berada di peringkat 32. Namun demikian, Indonesia masih mengungguli Filipina yang berada di peringkat 47, Vietnam di peringkat 56, Laos di peringkat 83, Kamboja di peringkat 90, dan Myanmar di peringkat 131.

Pada tahun 2015-2016 Indonesia berada pada posisi 37 (skor 4,52) masih berada dibawah Negara Singapore (2) Malaysia (16) dan Thailand (32). Pada tahun 2016-2017 posisi Indonesia turun menjadi poisisi 41 (skor 4,52) tetap masih berada dibawah Negara Singapore (2) Malaysia (25) dan Thailand (34). Dan pada tahun 2017-2018 Indonesia berada pada poisisi $36(4,68)$ masih berada dibawah Negara Singapore (3) Malaysia (23) dan Thailand (32). Memperhatikan hasil kajian seperti yang ditunjukkan dalam laporan Global Competetitiveness Report dari World Economic Forum, hal ini merupakan gambaran dari kondisi birokrasi di Indonesia saat ini yang belum optimal dan maksimal.

Sementara itu, Kementerian Pendayagunaan Aparatur Negara Reformasi Birokrasi merilis rapor perkembangan nilai akuntabilitas kinerja Pemerintah Provinsi Tahun 2015 yang dilansir oleh situs duajurai.com online (Fakhrurozi, 2016:5 Januari). Nilai akuntabilitas kinerja Pemerintah Provinsi Riau berada pada peringkat 25 (skor 54,73) dari 34 Provinsi se-Indonesia.

Kementerian Pendayagunaan Aparatur Negara dan Reformasi Birokrasi (KemenpanRB) melaksanakan evaluasi pelaksanaan Reformasi Birokrasi di 34 Provinsi se-Indonesia untuk tahun pelaksanaan 2016. Evaluasi dilakukan terhadap 8 area perubahan Reformasi Birokrasi yakni Mental Aparatur, Pengawasan, Akuntabilitas, Kelembagaan, Tatalaksana, SDM Aparatur, Peraturan Perundang-Undangan, dan Pelayanan Publik. Evaluasi juga dilakukan terhadap indeks Reformasi Birokrasi masing-masing pemerintah daerah (provinsi) serta tanggapan masyarakat pengguna layanan, yang dilakukan dengan penilaian lapangan. Provinsi Riau mendapatkan Nilai CC msih berada dibawah Provinsi tetangga yakni Kepulauan Riau (Nilai B), Sumatera Barat (B), dan NAD (B).

Dari hasil evaluasi akuntabilitas kinerja pemerintah tahun 2015 yang diserahkan Menpan, Kabupaten Inhu meraih predikat CC bersama sejumlah kabupaten/kota lain di Riau. Diantaranya, Kabupaten Bengkalis, Kampar, Dumai dan Rokan Hulu. Sementara, lima kabupaten lain seperti, Kabupaten Rokan Hilir, Kuansing, Pelawan, Inhil dan Kota Pekanbaru meraih predikat C (https://www.goriau.com/berita/indragiri-hulu/terima-hasilevaluasi-kinerja-dari-menpanrb-inhu-hanya-mampu-raih-peringkat-cc.html). Pada tahun 2016, Provinsi Riau di posisi 24 dari 34 provinsi se-Indonesia. Sedangkan kabupaten di Riau tingkat penyelenggaraan pemerintahan daerahnya masih jauh dari harapan. Dari 397 kabupaten se-Indonesia, Siak menduduki nomor 74, disusul Bengkalis 187, Indragiri Hulu diposisi 196, Kampar 214, Rokan Hulu 233, Pelalawan 249, Rokan Hilir 274, Indragiri Hilir 289, Kepulauan Meranti 294, dan Kuantan Singingi nomor 310. Sementara dari 93 kota di Indonesia, Kota Pekanbaru tercecer di nomor 51 dan Kota Dumai nomor 80. Atas hasil evaluasi terdapat penyelenggaraan pemerintah daerah secara nasional tahun 2016, tidak satu pun kabupaten/kota di Riau yang mendapat berprestasi paling tinggi. Termasuk provinsi menempati posisi 24 dari 33 provinsi di Indonesia (https://www.cakaplah.com/berita/baca/2018/04/26/ini-hasil-evaluasi-kinerjapenyelenggaraan-pemerintahan-daerah-di-riau-tahun-2016\#sthash.3LyjmgID.dpbs)

Kinerja Aparatur Sipil Negara Kabupaten Indragiri Hulu belum maksimal. Faktorfaktor yang mempengaruhi kinerja diantaranya iklim organisasi, kepemimpinan, 
kemampuan kerja, dan disiplin kerja (Robbins, 2008:121). Inilah dasar pemikiran penulis untuk melakukan penelitian mengenai: Pengaruh Iklim Organisasi, Kepemimpinan, Kemampuan Kerja, Dan Disiplin Kerja Terhadap Kinerja Aparatur Sipil Negara (ASN) Kabupaten Indragiri Hulu.

\section{METODE PENELITIAN}

Metode pengumpulan data yakni peneliti melakukan wawancara dan penyebaran kuesioner. Dalam penelitian ini yang menjadi populasi adalah Aparatur Sipil Negara yang berstatus Pegawai Negeri Sipil Kabupaten Indragiri Hulu tahun 2017 sebanyak 2.941 orang. Penentuan ukuran sampel dalam penelitian ini dilakukan dengan menggunakan rumus Slovin sebagai berikut : (Sugiyono, 2006:57)

$$
\begin{aligned}
& \mathrm{n}=\frac{\mathrm{N}}{1+\mathrm{Ne}^{2}} \\
& \mathrm{n}=\frac{2.941}{1+2.941(10 \%)^{2}} \\
& \mathrm{n}=97 .
\end{aligned}
$$

Jadi, sampel penelitian ini sebanyak 97 orang/ responden. Metode pengambilan sampel menggunakan Purposive Sampling yaitu teknik pengambilan sampel yang peneliti jumpai atau temui yang ditentukan oleh peneliti.

Teknik analisis data yang penulis gunakan melalui beberapa tahapan, yakni:

1. Uji Instrumen

a. Uji Validitas

Uji Validitas adalah uji untuk mengetahui tingkat valid dari instrument kuesioner yang dipergunakan dalam pengumpulan data. Untuk mengetahui konsistensi dan akurasi data yang dikumpulkan dari penggunaan instrumen kuesioner dilakukan uji validitas dengan menggunakan korelasi Spearman Rank. Sebuah item dikatakan valid bila $r$ hitung $>r$ tabel (Sugiyono, 2008).

b. Uji Reliabilitas

Uji reliabilitas digunakan untuk mengetahui adanya konsistensi alat ukur dalam penggunaannya atau dapat dikatakan bahwa reliabilitas menunjukkan sejauh mana suatu instrumen dapat memberikan hasil pengukuran yang konsisten.

Dikatakan reliabel membandingkan $r$ hitung dengan $r_{\text {tabel }}$. Apabila $r$ hitung lebih besar dari $r_{\text {tabel }}\left(r_{h}>r_{t}\right)$ maka butir instrumen tersebut reliabel, tetapi sebaliknya bila $r_{\text {hitung }}$ lebih kecil dari $r_{\text {tabel }}\left(r_{h}<r_{t}\right)$ maka instrumen tersebut tidak reliabel. (Sandjojo, 2011:152)

2. Uji Asumsi Klasik

a. Uji Normalitas

Uji Normalitas bertujuan untuk mengukur apakah dalam model regresi terdapat variabel pengganggu atau residual memiliki distribusi normal (Ghozali, 2009:110). Model regresi yang baik adalah distribusi data normal atau mendekati normal. Data menyebar di sekitar garis diagonal dan mengikuti arah garis diagonal, maka model regresi memenuhi asumsi normalitas. Jika data menyebar jauh dari garis diagonal dan atau tidak mengikuti arah garis diagonal, maka model regresi tidak memenuhi asumsi normalitas.

b. Uji Multikolinieritas

Uji multikolinieritas bertujuan untuk menguji apakah model regresi ditemukan adanya korelasi antar variabel bebas. Jika antar variabel bebas terdapat korelasi yang cukup tinggi maka terjadi multikolinieritas. Model regresi yang baik seharusnya tidak terjadi korelasi variabel bebas tersebut (Ghozali, 2009:114). 


\section{c. Uji Heteroskedastisitas}

Menurut Ghozali (2009:115), uji heteroskedastisitas bertujuan untuk menguji apakah model regresi terjadi ketidaksamaan variance dari residual satu pengamatan ke pengamatan lainnya. Heteroskedastisitas akan terjadi apabila variance $\varepsilon$ (gangguan/ disturbance) tidak mempunyai penyebaran yang sama sehingga model yang sudah dibuat menjadi kurang efisien.

3. Regresi Linear Berganda

Persamaan Regresi (Teguh, 2014:98):

$Y_{1}=a+b_{1} X_{1}+b_{2} X_{2}+b_{3} X_{3}++b_{4} X_{4}+e$

Keterangan :

$\mathrm{Y}=$ Kinerja, $\mathrm{X}_{1}=$ Iklim Organisasi, $\mathrm{X}_{2}=$ Kepemimpinan, $\mathrm{X}_{3}=$ Kemampuan, $\mathrm{X}_{4}$ $=$ Disiplin Kerja, $\mathrm{a}=$ Besarnya nilai $\mathrm{Y}$ apabila $\mathrm{X}=$ nol, $\mathrm{b}=$ Besarnya peningkatan $\mathrm{Y}$ apabila $\mathrm{X}$ meningkat 1 satuan, e = error/ tingkat kesalahan

4. Analisis Koefisien Korelasi

$$
\mathrm{r}=\frac{\sum X Y-\frac{\sum X \cdot \sum Y}{n}}{\sqrt{\left(\sum X^{2}-\left[\frac{\sum X}{n}\right]^{2}\right)\left(\sum Y^{2}-\left[\frac{\sum Y}{n}\right]^{2}\right)}}
$$

5. Koefisien Determinasi $\left(\mathrm{R}^{2}\right)$

$\mathrm{R}$ Square $(\mathrm{R})$ atau Koefesien Determinasi $(\mathrm{KD})=(\mathrm{r})^{2} \times 100 \%$

6. Uji Statistik (Uji F)

Apabila $\mathrm{F}$ hitung > F tabel artinya Ha diterima dan Ho ditolak, maka ada pengaruh yang signifikan secara bersama-sama antara variabel $\mathrm{X}$ dan Variabel $\mathrm{Y}$ Apabila $\mathrm{F}$ hitung < $\mathrm{F}$ tabel artinya Ha ditolak dan Ho diterima, maka tidak ada pengaruh yang signifikan secara bersama-sama antara variabel $\mathrm{X}$ dan Variabel Y

7. Uji Statistik (Uji t)

Uji yang dilakukan untuk koefisien regresi ini adalah uji statistik:

Los $(\alpha)$ (level of significance) / batas Toleransi antara 5\% s/d 10\%.

Rumus t Tabel $=\alpha / 2 ; \mathrm{n}-2$

\section{HASIL DAN PEMBAHASAN}

\section{Uji Instrumen}

a. Uji Validitas

Tabel 1:Hasil Pengujian Validitas

\begin{tabular}{c|c|c|c|c|c}
\hline Variabel & Pertanyaan & Nilai $\mathbf{r}_{\text {hitung }}$ & Nilai $\mathbf{r}_{\text {tabel }}$ & Sig & Ket \\
\hline & P1 & 0,363 & 0,199 & 0,000 & Valid \\
& P2 & 0,426 & 0,199 & 0,000 & Valid \\
X $_{1}$ & P3 & 0,557 & 0,199 & 0,000 & Valid \\
Iklim Organisasi & P4 & 0,564 & 0,199 & 0,000 & Valid \\
& P5 & 0,658 & 0,199 & 0,000 & Valid \\
& P6 & 0,455 & 0,199 & 0,000 & Valid \\
& P1 & 0,607 & 0,199 & 0,000 & Valid \\
X $_{2}$ & P2 & 0,625 & 0,199 & 0,000 & Valid \\
Kepemimpinan & P3 & 0,664 & 0,199 & 0,000 & Valid \\
& P4 & 0,621 & 0,199 & 0,000 & Valid
\end{tabular}




\begin{tabular}{c|l|l|l|l|l} 
& P1 & 0,399 & 0,199 & 0,000 & Valid \\
$\begin{array}{c}\text { Kemampuan } \\
\text { Kerja }\end{array}$ & P2 & 0,420 & 0,199 & 0,000 & Valid \\
& P3 & 0,448 & 0,199 & 0,000 & Valid \\
& P4 & 0,532 & 0,199 & 0,000 & Valid \\
& P5 & 0,592 & 0,199 & 0,000 & Valid \\
X $_{4}$ & P6 & 0,458 & 0,199 & 0,000 & Valid \\
Disiplin Kerja & P1 & 0,484 & 0,199 & 0,000 & Valid \\
& P2 & 0,509 & 0,199 & 0,000 & Valid \\
& P3 & 0,411 & 0,199 & 0,000 & Valid \\
& P4 & 0,431 & 0,199 & 0,000 & Valid \\
& P5 & 0,528 & 0,199 & 0,000 & Valid \\
Y & P1 & 0,400 & 0,199 & 0,000 & Valid \\
Kinerja & P2 & 0,492 & 0,199 & 0,000 & Valid \\
& P3 & 0,495 & 0,199 & 0,000 & Valid \\
& P4 & 0,620 & 0,199 & 0,000 & Valid \\
& P5 & 0,634 & 0,199 & 0,000 & Valid \\
& P6 & 0,403 & 0,199 & 0,000 & Valid \\
& P7 & 0,500 & 0,199 & 0,000 & Valid \\
& P8 & 0,445 & 0,199 & 0,000 & Valid \\
\hline
\end{tabular}

Sumber : Data Olahan

Berdasarkan tabel 1 di atas dapat dilihat semua pertanyaan berjumlah 29 butir pertanyaan dengan nilai $r_{\text {hitung }}>$ nilai $r_{\text {tabel }}$ atau nilai Sig $<\alpha 0,05$, dapat disimpulkan bahwa semua pertanyaan adalah valid.

b. Uji Reliabilitas

Tabel 2: Hasil Pengujian Reliabilitas.

\begin{tabular}{c|c|c|c|c}
\hline Variabel & $\begin{array}{c}\text { N of } \\
\text { Items }\end{array}$ & $\begin{array}{c}\text { Crobach's } \\
\text { Alpha }\end{array}$ & Nilai $\mathbf{r}_{\text {tabel }}$ & Ket \\
\hline Iklim organisasi (X1) & 6 & 0,413 & 0,199 & Reliabel \\
Kepemimpinan (X2) & 4 & 0,491 & 0,199 & Reliabel \\
Kemampuan Kerja (X3) & 6 & 0,314 & 0,199 & Reliabel \\
Disiplin Kerja (X4) & 5 & 0,231 & 0,199 & Reliabel \\
Kinerja (Y) & 8 & 0,568 & 0,199 & Reliabel \\
\hline
\end{tabular}

Sumber : Data Olahan

Berdasarkan tabel 2 dapat dilihat semua nilai reliabilitas dengan menggunakan metode Cronbach Alpha, nilai $\mathrm{r}$ hitung $>\mathrm{r}_{\text {tabel }}$, sehingga dapat disimpulkan bahwa semua pertanyaan variabel pertanyaan telah reliabel, dan dapat digunakan kedalam analisis lebih lanjut. 


\section{Uji Asumsi Klasik}

a. Uji Normalitas

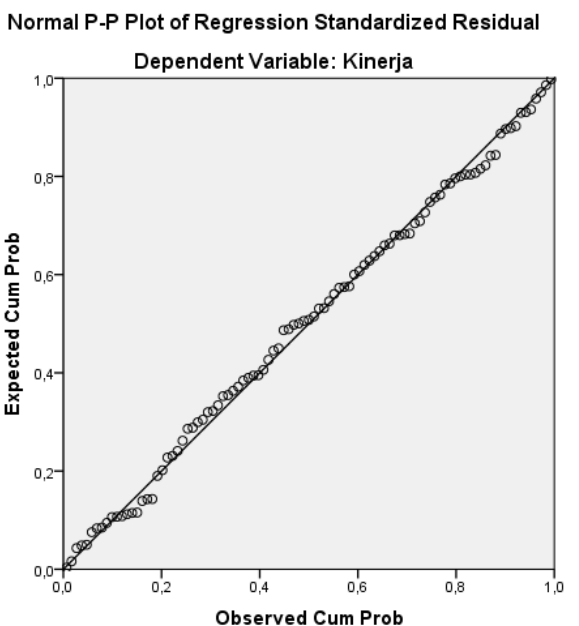

Sumber : Data Olahan SPSS

Gambar 1 : Diagram Normalitas Data

Pada gambar 1, dapat dilihat distribusi data mengikuti garis diagonal, artinya data mengikuti kriteria data normal.

\section{b. Pengujian Multikolinieritas}

Tabel 3 : Uji Multikolinieritas

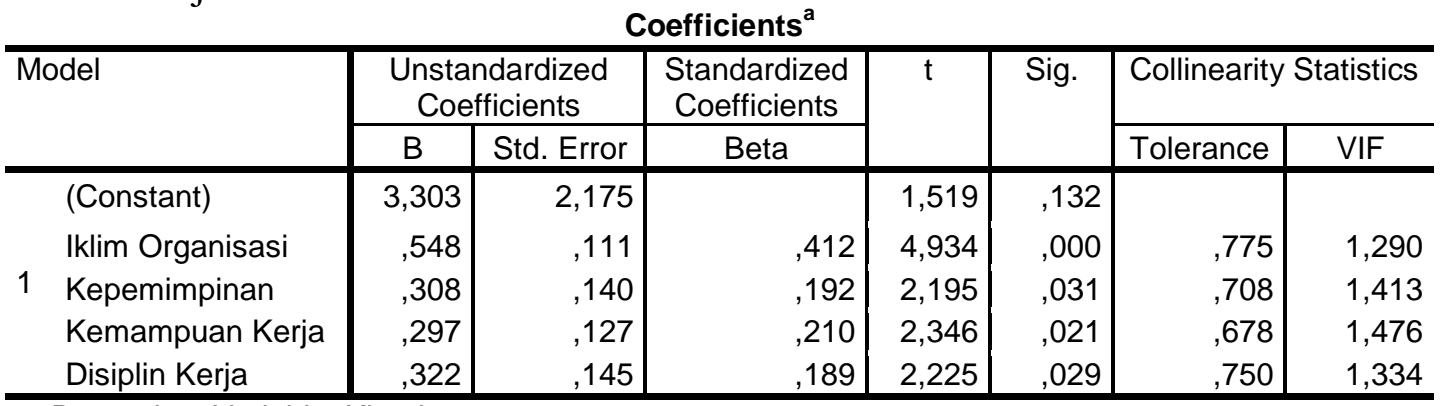

a. Dependent Variable: Kinerja

Sumber : Data Olahan SPSS

Untuk variabel iklim organisasi, nilai VIF sebesar $1,290<10$ dengan nilai tolerance sebesar 0,775 >0,10. Untuk variabel kepemimpinan, nilai VIF sebesar 1,413 $<10$ dengan nilai tolerance sebesar 0,708 > 0,10. Untuk variabel kemampuan kerja, nilai VIF sebesar 1,476 < 10 dengan nilai tolerance sebesar 0,678 >0,10. Dan untuk variabel disiplin kerja, nilai VIF sebesar 1,334 < 10 dengan nilai tolerance sebesar $0,750>0,10$. Sehingga dapat disimpulkan bahwa model regresi dalam penelitian ini tidak terjadi gejala korelasi antar variabel. 


\section{c. Pengujian Heteroskedastisitas}

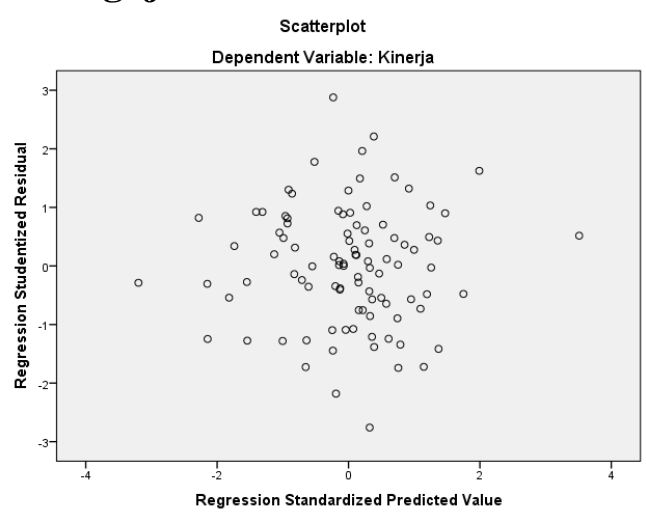

Sumber : Data Olahan SPSS

\section{Gambar 2 : Diagram Uji Heteroskedastisitas}

Dari Gambar 2, terlihat bahwa titik-titik menyebar secara acak tidak membentuk pola tertentu yang jelas, serta tersebar diatas dan dibawah angka nol (0) pada sumbu Y. Oleh karena itu, dapat disimpulkan bahwa model regresi dalam penelitian ini bebas heteroskedastisitas.

\section{Analisis Regresi Linear Berganda}

Tabel 4 :Rekapitulasi Hasil Uji Regresi Linear Berganda

\begin{tabular}{|c|c|c|c|c|c|c|c|c|}
\hline \multirow{2}{*}{\multicolumn{2}{|c|}{ Model }} & \multicolumn{2}{|c|}{$\begin{array}{l}\text { Unstandardized } \\
\text { Coefficients }\end{array}$} & $\begin{array}{l}\text { Standardized } \\
\text { Coefficients }\end{array}$ & \multirow[t]{2}{*}{$\mathrm{t}$} & \multirow[t]{2}{*}{ Sig. } & \multicolumn{2}{|c|}{ Collinearity Statistics } \\
\hline & & $B$ & Std. Error & Beta & & & Tolerance & VIF \\
\hline \multirow{5}{*}{1} & (Constant) & 3,303 & 2,175 & & 1,519 & ,132 & & \\
\hline & Iklim Organisasi & ,548 & ,111 & ,412 & 4,934 &, 000 & ,775 & 1,290 \\
\hline & Kepemimpinan & ,308 & , 140 & , 192 & 2,195 &, 031 & ,708 & 1,413 \\
\hline & Kemampuan Kerja & 297, & 127, & 210, & 2,346 & 021 & 678 & 1,476 \\
\hline & Disiplin Kerja & ,322 & 145 & 189 & 2,225 & 029 & ,750 & 1,334 \\
\hline
\end{tabular}

a. Dependent Variable: Kinerja

Sumber : Data Olahan

$$
Y=3,303+0,548 X_{1}+0,308 X_{2}+0,297 X_{3}+0,322 X_{4}
$$

Penjelasan regresinya adalah:

$\mathrm{a}=3,303$

Jika iklim organisasi, kepemimpinan, iklim organisasi dan displin kerja sama dengan 0 (nol) maka besarnya kinerja sebesar 3,303 poin.

$\mathrm{b} 1=0,548$

Jika iklim organisasi meningkat sebesar 1 (satu) satuan, maka kinerja akan mengalami peningkatan sebesar 0,548 poin.

$\mathrm{b} 2=0,308$

Jika kepemimpinan meningkat sebesar 1 (satu) satuan, maka kinerja akan mengalami peningkatan sebesar 0,308 poin.

$\mathrm{b} 3=0,297$

Jika kemampuan kerja meningkat sebesar 1 (satu) satuan, maka kinerja akan mengalami peningkatan sebesar 0,297 poin.

$\mathrm{b} 4=0,322$

Jika disiplin kerja meningkat sebesar 1 (satu) satuan, maka kinerja akan mengalami peningkatan sebesar 0,322 poin. 


\section{Uji Simultan}

Tabel 5 : Hasil Uji Simultan

\begin{tabular}{|c|c|c|c|c|c|c|}
\hline \multicolumn{7}{|c|}{ ANOVA $^{a}$} \\
\hline & & Sum of Squares & $\mathrm{df}$ & Mean Square & $F$ & Sig. \\
\hline \multirow{3}{*}{1} & Regression & 635,725 & 4 & 158,931 & 23,151 &, $000^{\circ}$ \\
\hline & Residual & 631,586 & 92 & 6,865 & & \\
\hline & Total & 1267,310 & 96 & & & \\
\hline
\end{tabular}

a. Dependent Variable: Kinerja

b. Predictors: (Constant), Disiplin Kerja, Kepemimpinan, Iklim Organisasi, Kemampuan Kerja Sumber : Data Olahan

Diperoleh nilai $F_{\text {hitung }} 23,151>F_{\text {tabel }} 2,47$, maka berdasarkan kriteria pengujian data dapat diketahui bahwa $\mathrm{H}_{\mathrm{a}}$ diterima dan $\mathrm{H}_{0}$ ditolak, artinya iklim organisasi, kepemimpinan, kemampuan kerja dan disiplin kerja secara bersama-sama (simultan) berpengaruh signifikan terhadap kinerja.

\section{Uji t}

Tabel 6: Hasil SPSS Uji t (Parsial)

\begin{tabular}{|c|c|c|c|c|c|c|c|c|}
\hline \multirow{3}{*}{\multicolumn{2}{|c|}{ Model }} & \multicolumn{4}{|c|}{ Coefficients $^{a}$} & & \\
\hline & & \multicolumn{2}{|c|}{$\begin{array}{c}\text { Unstandardized } \\
\text { Coefficients }\end{array}$} & \multirow{2}{*}{$\begin{array}{c}\text { Standardized } \\
\text { Coefficients } \\
\text { Beta }\end{array}$} & \multirow[t]{2}{*}{$\mathrm{t}$} & \multirow[t]{2}{*}{ Sig. } & \multicolumn{2}{|c|}{ Collinearity Statistics } \\
\hline & & $\mathrm{B}$ & Std. Error & & & & Tolerance & VIF \\
\hline \multirow{5}{*}{1} & (Constant) & 3,303 & 2,175 & & 1,519 & ,132 & & \\
\hline & Iklim Organisasi &, 548 & 111 & ,412 & 4,934 & ,000 & ,775 & 1,290 \\
\hline & Kepemimpinan & ,308 & 140 & 192 & 2,195 & 031 & ,708 & 1,413 \\
\hline & Kemampuan Kerja & ,297 & , 127 & ,210 & 2,346 & 021 & 678 & 1,476 \\
\hline & Disiplin Kerja & ,322 & , 145 & ,189 & 2,225 & ,029 & ,750 & 1,334 \\
\hline
\end{tabular}

a. Dependent Variable: Kinerja

Sumber : Data Olahan

\section{a). Pengaruh Iklim Organisasi (X1) secara parsial terhadap Kinerja (Y)}

Untuk variabel iklim organisasi, diperoleh $t_{\text {hitung }}>t_{\text {tabel }}$ yaitu 4,934 $>1,9853$. Berdasarkan kriteria pengujian data dapat diketahui bahwa $\mathrm{H}_{\mathrm{a}}$ diterima dan $\mathrm{H}_{0}$ ditolak artinya iklim organisasi secara parsial berpengaruh signifikan terhadap kinerja.

b). Pengaruh Kepemimpinan (X2) secara parsial terhadap Kinerja (Y)

Untuk variabel kepemimpinan, diperoleh $t_{\text {hitung }}>t_{\text {tabel }}$ yaitu 2,195 $>1,9853$. Berdasarkan kriteria pengujian data dapat diketahui bahwa $\mathrm{H}_{\mathrm{a}}$ diterima dan $\mathrm{H}_{0}$ ditolak artinya kepemimpinan secara parsial berpengaruh signifikan terhadap kinerja.

\section{c). Pengaruh Kemampuan Kerja (X3) secara parsial terhadap Kinerja (Y)}

Untuk variabel kemampuan kerja, diperoleh $t_{\text {hitung }}>t_{\text {tabel }}$ yaitu 2,346 $>1,9853$. Berdasarkan kriteria pengujian data dapat diketahui bahwa $\mathrm{H}_{\mathrm{a}}$ diterima dan $\mathrm{H}_{0}$ ditolak artinya kemampuan kerja secara parsial berpengaruh signifikan terhadap kinerja.

\section{d). Pengaruh Disiplin Kerja (X4) secara parsial terhadap Kinerja (Y)}

Untuk variabel disiplin kerja, diperoleh $t_{\text {hitung }}>t_{\text {tabel }}$ yaitu 2,225 $>1,9853$. Berdasarkan kriteria pengujian data dapat diketahui bahwa $\mathrm{H}_{\mathrm{a}}$ diterima dan $\mathrm{H}_{0}$ ditolak artinya disiplin kerja secara parsial berpengaruh signifikan terhadap kinerja. 


\section{Koefisien Korelasi dan Koefisien Determinasi}

Tabel 7 : Koefisien Korelasi dan Determinasi

\begin{tabular}{|c|c|c|c|c|c|}
\hline \multicolumn{6}{|c|}{ Model Summary ${ }^{b}$} \\
\hline Model & $\mathrm{R}$ & R Square & $\begin{array}{c}\text { Adjusted R } \\
\text { Square }\end{array}$ & $\begin{array}{c}\text { Std. Error of the } \\
\text { Estimate }\end{array}$ & Durbin-Watson \\
\hline 1 &, $708^{\mathrm{a}}$ &, 502 & ,480 & 2,620126 & 2,049 \\
\hline
\end{tabular}

Tabel 8 : Skala Koefisien Korelasi

\begin{tabular}{c|c}
\hline Koefisien Korelasi $(\mathrm{r})$ & Hubungan \\
\hline $0,00-0,199$ & Sangat Lemah \\
$0,20-0,979$ & Lemah \\
$0,40-0,599$ & Sedang \\
$0,60-0,799$ & Kuat \\
$0,80-1,0$ & Sangat Kuat \\
\hline
\end{tabular}

Nilai R atau korelasi yang terlihat dari tabel 7 adalah 0,708 artinya mempunyai hubungan yang kuat serta searah antara iklim organisasi, kepemimpinan, kemampuan kerja dan disiplin dengan kinerja, maksudnya apabila iklim organisasi, kepemimpinan, kemampuan kerja dan disiplin kerja meningkat maka kinerja juga akan meningkat dan diperoleh nilai R Square atau koefisien determinasi $\left(\mathrm{R}^{2}\right)$ yang terlihat dari tabel 7 adalah 0,502 artinya variabel kinerja dapat dijelaskan oleh variabel iklim organisasi, kepemimpinan, kemampuan kerja dan disiplin kerja sebesar 50,2\%, sedangkan sisanya sebesar 49,8\% dijelaskan oleh variabel-variabel bebas lainnya yang tidak diteliti.

\section{PENUTUP}

Berdasarkan uji simultan disimpulkan bahwa iklim organisasi, kepemimpinan, kemampuan kerja dan disiplin kerja secara bersama-sama berpengaruh signifikan terhadap kinerja Aparatur Sipil Negara. Iklim organisasi secara parsial berpengaruh signifikan terhadap kinerja, artinya semakin baik iklim organisasi maka akan meningkatkan kinerja Aparatur Sipil Negara. Kepemimpinan secara parsial berpengaruh signifikan terhadap kinerja, artinya semakin meningkat kepemimpinan maka kinerja Aparatur Sipil Negara juga akan meningkat. Kemampuan kerja secara parsial berpengaruh signifikan terhadap kinerja, artinya semakin meningkat kemampuan kerja, maka akan meningkatkan kinerja Aparatur Sipil Negara. Disiplin kerja secara parsial berpengaruh signifikan terhadap kinerja, artinya semakin bagus disiplin kerja, maka akan meningkat pula kinerja Aparatur Sipil Negara.

\section{DAFTAR PUSTAKA}

Abubakar, Azwar. 2014. Orasi Ilmiah: Reformasi Birokrasi Untuk Meningkatkan Daya Saing Bangsa. Menteri Pendayagunaan Aparatur Negara dan Reformasi Birokrasi.

Peraturan Pemerintah Republik Indonesia Nomor 46 Tahun 2011 Tentang Penilaian Prestasi Kerja Pegawai Negeri Sipil. 
Sasmita, Jumiati. 2012. Pengaruh Pengembangan Karir Terhadap Motivasi Dan Kinerja Pegawai Negeri Sipil Di Provinsi Riau. Prosiding Seminar \& Konferensi Nasional Manajemen Bisnis, pp. 80:90.

Sedarmayanti.2010. Manajemen Sumber Daya Manusia Reformasi Birokrasidan Manajemen Pegawai Negeri Sipil.Bandung; PT Refka Aditama.

Sugiyono. 2007. Statistika untuk Penelitian. CV. Alfabeta. Bandung.

Sugiyono. 2010. Metode Peneltiian Kuantitaif Kualitatif \& RND. CV. Alfabeta. Bandung.

Syadam, Gouzali. 2005. Manajemen Sumber Daya Manusia: Suatu Pendekatan Mikro. Jakarta: Djambatan.

Utama, Donny Prakasa. 2010. Pengaruh Disiplin Kerja Dan Sistem Kompensasi Pegawai Negeri Sipil Terhadap Kinerja Pegawai Negeri Sipil Di Badan Kepegawaian Negara. Tesis. Jakarta: Universitas Indonesia.

Wibowo. 2014. Manajemen Kinerja. Rajawali Pers. Jakarta.

https://www.cakaplah.com/berita/baca/2018/04/26/ini-hasil-evaluasi-kinerjapenyelenggaraan-pemerintahan-daerah-di-riau-tahun2016\#sthash.3LyjmgID.dpbs

https://www.goriau.com/berita/indragiri-hulu/terima-hasil-evaluasi-kinerja-dari-menpanrbinhu-hanya-mampu-raih-peringkat-cc.html 